\title{
Benchmarking biofuels-a comparison of technical, economic and environmental indicators
}

\author{
Franziska Müller-Langer ${ }^{1 *}$, Stefan Majer ${ }^{2}$ and Sinéad O'Keeffe ${ }^{3}$
}

\begin{abstract}
The global demand for energy, particularly for transport fuels, will continue to increase significantly in the future. In addition to other options, like increased technological efficiencies, traffic reduction or modal shift, biofuels are promoted to contribute strongly to the transport sector in the years to come. Biofuels are also promoted as part of the EU strategy for decarbonising the transport sector with the aim of reducing associated GHG emissions. This paper considers some of the most important biofuels. A selection of biofuel options (biodiesel, bioethanol, biomethane, hydrotreated vegetable oils and fats, lignocellulosic-based fuels) were characterised by their conversion technologies and stage of development. They were analysed, concerning technical (overall efficiency), economic (investments and biofuel production costs) and environmental aspects (GHG performance). Additionally, GHG mitigation costs were calculated with regard to the GHG-based biofuel quota.
\end{abstract}

Keywords: Biofuel; Conversion technologies; Costs; GHG mitigation

\section{Review}

\section{Introduction}

The transport sector accounts for half of the global mineral oil consumption, nearly $20 \%$ of world energy used today and it is expected to increase in the coming years. On a global level, about $116 \mathrm{EJ} \mathrm{a}^{-1}$ are expected until 2050 i.e. an increase of approximately $25 \%$ compared to 2009 $\left(93 \mathrm{EJ} \mathrm{a}^{-1}\right)$ [1]. Biofuels are promoted as one of the best means to help meet the prospected increases in energy demand in the years to come, in addition to other options like improved technological efficiency (e.g. of propulsion systems for electric vehicles), traffic reduction or modal shift (e.g. from road to rail systems). Despite one or two exceptions, biofuel use is driven by governmental policies and regulations. The most important drivers of the biofuels market are security of energy supply (e.g. in America and Asia), mitigation of greenhouse gases (e.g. in Europe) and the diversification of fuel sources to buffer against the instabilities of fossil fuel prices (e.g. in Brazil). Currently, the global biofuel production is estimated to be $2.9 \mathrm{EJ} \mathrm{a}^{-1}$ [2]. The total biofuel demand is expected to meet approximately $27 \%\left(32 \mathrm{EJ} \mathrm{a}^{-1}\right)$ of the total transport fuel demand

\footnotetext{
* Correspondence: franziska.mueller-langer@dbfz.de

${ }^{1}$ Department Biorefineries, Deutsches Biomasseforschungszentrum gemeinnützige GmbH, Torgauer Straße 116, 04347 Leipzig, Germany Full list of author information is available at the end of the article
}

in 2050, with the majority of biofuels still being used for road transport, followed by aviation and shipping (Figure 1). Taking into account specific fuel quality requirements (e.g. propulsion systems and emission standards), in the IEA blue map scenario, an increase in high-quality diesel fuels (synthetic biodiesel and hydrotreated fuels) instead of conventional biodiesel and biomethane as well as a shift from corn-based bioethanol to lignocellulosic bioethanol are expected by 2050 [3]. Compared to this biofuel mix outlined in this scenario, the maximum technical biofuel potential estimated at 6.5 EJ a ${ }^{-1}$ for 2020 and a total technical raw material potential in the range of $100-300 \mathrm{EJ} \mathrm{a}^{-1}$ for 2050 seem possible [4].

Some biofuels have the potential to significantly enhance energy security (e.g. with regard to storable energy, regional supply and substituting fossil fuels), achieve GHG mitigation targets compared to fossil fuels, as well as providing the opportunity to diversify agriculture systems to providing both fuel and food, while simultaneously supporting rural communities. However, biofuels have undergone much scrutiny in the past number of years particularly in relation to the 'fuel vs food' debate and have been perceived less positively as a result. Therefore, more stringent regulations and strategies are being introduced in order to facilitate appropriate allocation of land 


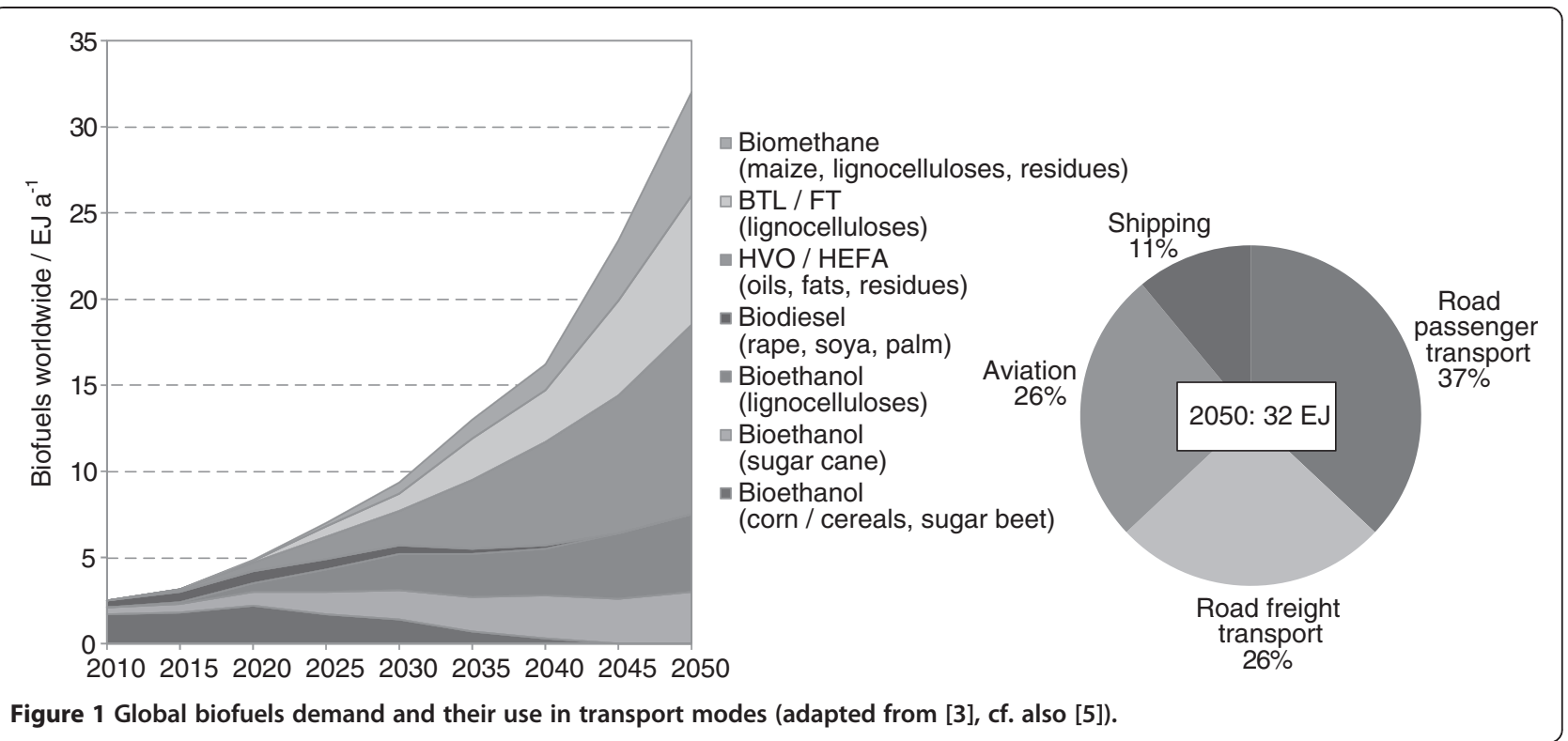

and efficient use of land, in order to produce both food and fuels $[6,7]$.

Biofuels are promoted as part of the EU's proposal for decarbonising the transport sector with the aim of reducing the associated GHG emissions. The main instruments at the EU level are the directives 2009/28/EC and $2009 / 30 / \mathrm{EC}[7,8]$. Both directives define specific goals for the share of renewables within the transport sector of $10 \%$ by 2020 , as well as a GHG reduction target for the entire transport fuel sector of $6 \%$ in 2020 . They have to be implemented in each of the European member states. Further to this, Germany proposes to introduce from 2015 a GHG mitigation quota. This means that fossil fuel companies will be obligated to blend the respective biofuel with its fossil counterpart petrol or diesel, in order to produce a fuel mix which achieves a 7\% GHG mitigation (compared to fossil gasoline and diesel mix) for the entire fuel sector by 2020 [9].

Therefore, in light of these targets, the aim of this paper is to show how a selection of current biofuel and future biofuel options (2050) identified as the most important by the IEA biofuels roadmap (Figure 1) can be assessed regarding certain technical, economic and environmental criteria. This was done in order to provide a greater insight into the important drivers for biofuel production routes and to understand the complexity of comparisons to be made, when trying to develop a benchmark for such conversion systems. Different studies and publications were screened to enable a basis of comparison between the different biofuel options. Additionally, in light of the proposed GHG mitigation quota for Germany, an overall indicator to assess the potential costs of GHG mitigation was estimated.

\section{Characteristics of biofuel conversion pathways}

There are various options to produce liquid and gaseous fuels from biomass with clearly defined fuel characteristics that comply with the regulated fuel quality standards. Depending on the biomass utilised, there are three main conversion options: physico-chemical, biochemical and thermo-chemical which were considered. All three pathways were characterised by different grades of technological complexity and flexibility [10,11], as well as different production configurations, shown in Figure 2.

A selection of the most important biofuels are summarised in Table 1, using the most relevant characteristics that need to be taken into account when making assessments of such biofuels. These include: raw materials, conversion steps involved in the production chain, relevant by-products that arise during the production process, state of technical development, current installed capacity, as well as the R\&D challenges of these biofuel options. The interaction of all of these variables plays an important role in why and how certain biofuel options are more successful than others. Conventional biofuels, or first generation biofuels, such as biodiesel and bioethanol are based on traditionally grown vegetable oil crops, sugar and starch crops, respectively. Well-established technologies are applied for their production and the biofuels are available on the global market in considerable amounts. Additionally, by-products from biofuel production can be used as fodder for livestock (e.g., extraction meal, vinasse, distiller's grains with solubles (DDGS)) and as raw materials in the chemical industry (e.g., glycerine and salt fractions) (Table 1).

In contrast, biofuels with a lower technology readiness level (Table 1), or second generation biofuels, can be 


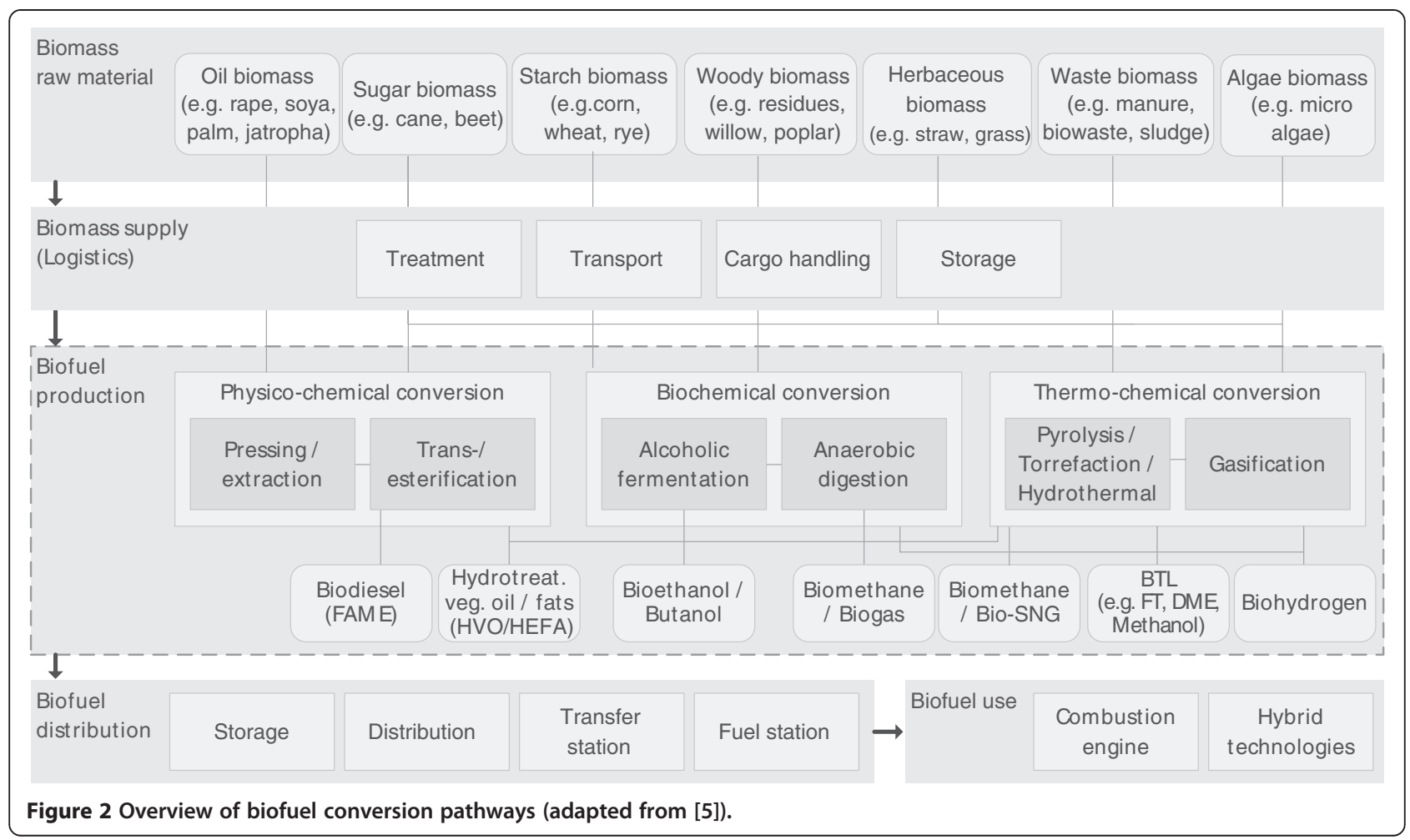

produced via bio- and thermo-chemical conversion routes from: (i) the whole crop or (ii) a diversified range of raw materials, including biowastes or residue streams that are rich in lignin and cellulose (e.g., straw, grass or wood) (Figure 2). Usually, for such biofuels (e.g., synthetic fuels), production plants and the surrounding infrastructure are comparably more complex than for conventional ones.

Within a certain biofuel route (e.g., bioethanol and synthetic fuels), overall biofuel conversion plant concepts can vary quite extensively; they cannot be bought 'off the shelf'. Referring to the existing biofuel plants, the realised concepts depend on regionally specific conditions, i.e. the equipment provider, as well as certain optimisations made by the biofuel production plant operators themselves (e.g., with regard to increase efficiency during operation). Therefore, each biofuel plant can be considered as an individual concept. Moreover, due to these customised designs, many biofuel concepts show the potential to be part of biorefineries that can function as a multiproduct provider (e.g., biofuels, bulk chemicals, supply of surplus power and heat).

\section{Technical comparison-production efficiency}

Biomass and the land utilised for its production are limited resources, therefore, the efficient and sustainable conversion of a biomass into the various related products is of the utmost importance $[15,16]$. The efficiency with which a biomass raw material can be converted into an energy carrier is one of the most important criteria for a biofuel production chain.

Thus for biofuel production plants, the technical efficiency was assessed, taking into account the input/output mass and energy streams (i.e. biomass raw material, process energy or other energy-related auxiliaries, as well as the biofuel itself and relevant by-products supplied and delivered to and from a production plant without up- and downstream steps like biomass production and logistics). However, due to the mixture of different industrial practices observed in various publications, coupled with the application of different assessment approaches, it is often quite difficult to compare the overall energetic efficiency reported for a particular biofuel option. Therefore, the variance of these values needs to be normalised to enable a more comprehensive comparison of the overall energetic efficiency between the different biofuel production options. Mass and energy balances taken from publications and from the Deutsches Biomasseforschungszentrum (DBFZ) database [17] were used to calculate the net energetic efficiency associated with each of the biofuel options shown in Table 1. For all biofuel production plants calculated, the mass and energy balances included the following plant operations: biomass pre-treatment, biomass conversion to biofuel and final biofuel treatment, as well as auxiliary units, e.g. for process energy provision.

The overall energetic efficiency of biofuel production plants is defined as ratio between the total output energy and total input energy. The total input energy includes 
Table 1 Characteristics of selected biofuel options and their development status [2,5,11-13]

\begin{tabular}{|c|c|c|c|c|c|c|c|c|}
\hline & Raw materials & $\begin{array}{l}\text { Main conversion steps/plant } \\
\text { concept }\end{array}$ & By-products $^{a}$ & $R \& D$ & $\begin{array}{l}\text { Status of } \\
\text { technical } \\
\text { development }^{\mathrm{b}}\end{array}$ & $\begin{array}{l}\text { Plant } \\
\text { capacityc }\end{array}$ & $\begin{array}{l}\text { Installed } \\
\text { capacity | } \\
\text { biofuel } \\
\text { production } \\
\text { worldwide }^{\text {d }}\end{array}$ & $\begin{array}{l}\text { Installed } \\
\text { capacity | } \\
\text { biofuel } \\
\text { production } \\
\text { EU }^{\text {d }}\end{array}$ \\
\hline \multicolumn{9}{|l|}{ Liquid biofuels } \\
\hline Biodiesel (FAME) & $\begin{array}{l}\text { Oil crops (e.g., } \\
\text { rape, soya, palm), } \\
\text { animal fats, waste } \\
\text { oils (UCO, grease), }\end{array}$ & $\begin{array}{l}\text { Oil extraction (mechanical/solvent), } \\
\text { oil refining, trans-/esterification, } \\
\text { biodiesel cleaning and upgrading }\end{array}$ & $\begin{array}{l}\text { Press cake/extraction } \\
\text { meal, glycerine, salt } \\
\text { fractions, fatty acids, } \\
\text { oleochemicals }\end{array}$ & $\begin{array}{l}\text { Process optimisation with } \\
\text { regard to e.g., oil quality, } \\
\text { catalysts, auxiliary substitution' }\end{array}$ & $\begin{array}{l}\text { Commercial } \\
\text { TRL } 9\end{array}$ & 2-350 MW & $\begin{array}{l}1,835 \mathrm{mn} G J \\
a^{-1} \mid 624 \\
m n G J a^{-1}\end{array}$ & $\begin{array}{l}823 \mathrm{mn} G J \\
a^{-1} \mid 336 \\
m n \mathrm{GJ} \mathrm{a}^{-1}\end{array}$ \\
\hline $\begin{array}{l}\text { Hydrotreated } \\
\text { vegetable oils (HVO) } \\
\text { or hydroprocessed } \\
\text { esters and fatty } \\
\text { acids (HEFA) }\end{array}$ & $\begin{array}{l}\text { algae and micro } \\
\text { oils }\end{array}$ & $\begin{array}{l}\text { Oil extraction (mechanical/solvent), } \\
\text { oil refining, hydrotreating of oil, } \\
\text { isomerisation }\end{array}$ & $\begin{array}{l}\text { Extraction meal, } \\
\text { fractions like } \\
\text { naphtha, propane/ } \\
\text { butane, waxes }\end{array}$ & $\begin{array}{l}\text { Raw material diversification } \\
\text { (e.g., algae, micro oils, hydrothermal } \\
\text { oil), co-refining }{ }^{k} \text {, process optimisation } \\
\text { with regard to e.g., catalysts, } \mathrm{H}_{2} \\
\text { demand }\end{array}$ & $\begin{array}{l}\text { Commercial } \\
\text { TRL } 9\end{array}$ & $\begin{array}{l}255-265 \mathrm{MW} \\
(150-1,220 \mathrm{MW})\end{array}$ & $\begin{array}{l}102 \mathrm{mn} \\
\mathrm{GJ} \mathrm{a}^{-1} \mid \text { n.a. }\end{array}$ & $\begin{array}{l}65 \mathrm{mn} G J \\
\mathrm{a}^{-1} \mid 46 \mathrm{mn} \\
\mathrm{GJ} \mathrm{a}^{-1} \\
\text { (estimation) }\end{array}$ \\
\hline $\begin{array}{l}\text { Bioethanol } \\
\text { (conventional) }\end{array}$ & $\begin{array}{l}\text { Sugar (e.g., beets } \\
\text { and cane) or starch } \\
\text { (e.g., corn, wheat, } \\
\text { ye) }\end{array}$ & $\begin{array}{l}\text { Sugar extraction or hydrolysis/ } \\
\text { saccharification, C6 fermentation, } \\
\text { distillation, final dehydration }\end{array}$ & $\begin{array}{l}\text { From sugar based e.g., } \\
\text { bagasse and vinasse } \\
\text { From starch based e.g., } \\
\text { gluten, DDGS biogas/ } \\
\text { biomethane, technical } \\
\mathrm{CO}_{2}^{\mathrm{g}}\end{array}$ & $\begin{array}{l}\text { Process optimisation with regard } \\
\text { to e.g., upgrading stillages and } \\
\text { by-products }\end{array}$ & $\begin{array}{l}\text { Commercial } \\
\text { TRL } 9\end{array}$ & 38-450 MW & $\begin{array}{l}2,403 \mathrm{mn} G J \\
a^{-1} \mid 1,869 \\
m n G J a^{-1}\end{array}$ & $\begin{array}{l}179 \mathrm{mn} G J \\
a^{-1} \mid 123 \\
m n G J a^{-1}\end{array}$ \\
\hline $\begin{array}{l}\text { Bioethanol } \\
\text { (lignocellulose) }\end{array}$ & $\begin{array}{l}\text { Lignocelluloses } \\
\text { (e.g., straw, } \\
\text { bagasse, wood, } \\
\text { switch grass) }\end{array}$ & $\begin{array}{l}\text { Pretreatment (e.g., hydrolysis, } \\
\text { thermal, acid), saccharification, } \\
\text { C6/C5 fermentation, distillation, } \\
\text { final dehydration }\end{array}$ & $\begin{array}{l}\text { Intermediates }{ }^{\mathrm{h}} \text { like } \\
\text { lignin, pentoses, } \\
\text { fertiliser biogas }\left(\mathrm{P} \& \mathrm{H}^{\mathrm{i}}\right) \text {, } \\
\text { technical } \mathrm{CO}_{2}\end{array}$ & $\begin{array}{l}\text { Upscaling, applications for lignin } \\
\text { (e.g., conversion to fuel, chemicals } \\
\text { or for P\&H), pentoses, enzyme } \\
\text { use and efficiency increase }\end{array}$ & $\begin{array}{l}\text { Demonstration } \\
\text { TRL } 7\end{array}$ & $\begin{array}{l}0.5-5 \mathrm{MW} \\
(35-100 \mathrm{MW})\end{array}$ & $\begin{array}{l}2,96 \mathrm{mn} \\
\mathrm{GJ} \mathrm{a}^{-1} \mid \text { n.a., } \\
\text { often only } \\
\text { test } \\
\text { campaigns }\end{array}$ & $\begin{array}{l}0,51 \mathrm{mn} \mathrm{GJ} \\
\mathrm{a}^{-1} \mid \mathrm{n} \cdot \mathrm{a} \cdot \mathrm{.} \\
\text { often only } \\
\text { test } \\
\text { campaigns }\end{array}$ \\
\hline $\begin{array}{l}\text { Synthetic } \\
\text { biomass-to-liquids } \\
\text { (BTL) }\end{array}$ & $\begin{array}{l}\text { Lignocelluloses } \\
\text { (e.g., wood, straw, } \\
\text { mischanthus), } \\
\text { black liquor }\end{array}$ & $\begin{array}{l}\text { Pretreatment (e.g., mechanical, } \\
\text { drying, pyrolysis, hydrothermal), } \\
\text { gasification, gas treatment, } \\
\text { synthesis (e.g., Fischer-Tropsch, FT), } \\
\text { hydrocracking, distillation, } \\
\text { isomerisation }\end{array}$ & $\begin{array}{l}\text { From FT: waxes, } \\
\text { naphtha, P\&H }\end{array}$ & $\begin{array}{l}\text { Upscaling overall concepts but } \\
\text { downscaling of synthesis and } \\
\text { upgrading units Process } \\
\text { optimisation with regard e.g., } \\
\text { to syngas treatment, efficiency } \\
\text { increase, final fuel treatment }\end{array}$ & $\begin{array}{l}\text { Pilot for FT } \\
\text { fuels TRL } 6\end{array}$ & $\begin{array}{l}0.8-5 \mathrm{MW} \\
(40-300 \mathrm{MW})\end{array}$ & $\begin{array}{l}1 \mathrm{mn} \mathrm{GJ} \mathrm{a}^{-1} \mid \\
\text { n.a., often } \\
\text { only test } \\
\text { campaigns }\end{array}$ & $\begin{array}{l}\text { No plants } \\
\text { running }\end{array}$ \\
\hline
\end{tabular}


Table 1 Characteristics of selected biofuel options and their development status [2,5,11-13] (Continued)

\begin{tabular}{|c|c|c|c|c|c|c|c|c|}
\hline \\
\hline $\begin{array}{l}\text { Gaseous biofuels } \\
\text { Biomethane/biogas }\end{array}$ & $\begin{array}{l}\text { Residues }^{\mathrm{e}} \text { (e.g., } \\
\text { biowaste, } \\
\text { manure, stillage) }\end{array}$ & $\begin{array}{l}\text { Silaging, hydrolysis (optional), } \\
\text { anaerobic digestion, gas } \\
\text { treatment and upgrading }\end{array}$ & $\begin{array}{l}\text { P\&H, digestate, } \\
\text { fertiliser fractions }\end{array}$ & $\begin{array}{l}\text { Process optimisation with regard } \\
\text { to e.g., methane yields, enzyme } \\
\text { use, gas treatment }\end{array}$ & $\begin{array}{l}\text { Commercial } \\
\text { TRL } 9\end{array}$ & $0.5-50 \mathrm{MW}$ & $\begin{array}{l}60 \mathrm{GJ} \mathrm{a} \mathrm{a}^{-1} \mid \\
\text { n.a. }\end{array}$ & $\begin{array}{l}38 \mathrm{GJ} \mathrm{a}^{-1} \mathrm{l} \\
36 \mathrm{GJ} \mathrm{a}^{-1} \\
\text { (estimation) }\end{array}$ \\
\hline $\begin{array}{l}\text { Biomethane/ } \\
\text { synthetic natural } \\
\text { gas (SNG) }\end{array}$ & $\begin{array}{l}\text { Lignocelluloses } \\
\text { (e.g., wood and } \\
\text { straw) }\end{array}$ & $\begin{array}{l}\text { Pretreatment (e.g., mechanical, } \\
\text { drying, gasification, gas treatment, } \\
\text { synthesis (methanation), } \\
\text { gas upgrading }\end{array}$ & P\&H & $\begin{array}{l}\text { Upscaling, process optimisation: } \\
\text { with regard to e.g., syngas } \\
\text { treatment, efficiency increase, } \\
\text { adaption to decentralised concepts }\end{array}$ & $\begin{array}{l}\text { Demonstration } \\
\text { TRL } 7\end{array}$ & $\begin{array}{l}\text { 1-10 MW } \\
(20-200 \mathrm{MW})\end{array}$ & $\begin{array}{l}\text { Not realised } \\
\text { outside } \\
\text { Europe }\end{array}$ & $\begin{array}{l}0,092 \mathrm{mn} \\
\mathrm{GJ} \mathrm{a}^{-1} \mid \text { n.a., } \\
\text { often only } \\
\text { test } \\
\text { campaigns }\end{array}$ \\
\hline
\end{tabular}

asually depending on process design.

${ }^{\mathrm{b}}$ According to technology readiness level (TRL) of the European Commission, which outlines in detail the different research and deployment steps $(1=$ basic principles observed, $2=$ technology concept formulated, $3=$ experimental proof of concept, $4=$ technology validation in lab, $5=$ technology validation in relevant environment, $6=$ demonstration in relevant environment, $7=$ demonstration in operational environment $8=$ system completed and qualified, $9=$ successful mission operations) [14].

'Related to biofuel output-w/o brackets for current capacities, expected capacities in future in brackets (based on [5]).

dValues for 2012 or 2013; n.a.-no information available for biofuel production.

eMostly derived from sugar or starch-dominated substrates.

fStillage for DDGS (distiller's dried grains with solubles).

${ }^{9}$ Technical $\mathrm{CO}_{2}$ can be used for food or chemical industries (e.g., $\mathrm{CO}_{2}$ for fizzy drinks and for synthesis).

${ }^{\mathrm{h}} \mathrm{Can}$ be used as feedstock for another process or upgraded further.

'P\&H = (electrical) power and heat

jOne example of this is methanol substitution through bioethanol.

${ }^{\mathrm{k}} \mathrm{Co}$-refining in a mineral oil refinery. 
the energy balances related to the flow of raw materials (Table 1, such as oil seeds or crops, cereals, lignocellulosic wood chips or straw bales), auxiliaries with energetic relevance (e.g., for gas upgrading) and process energy that are supplied externally to the plant. The total output energy includes the energy associated with the main product (i.e. GJ of biofuel) and the energy associated with all other by-products (e.g., rape or soya extraction meal, glycerine, naphtha) including surplus process energy (e.g., electrical power and heat that is generated from exhaust heat or side streams out of the processes). Residues and waste heat streams were not included in the calculation [5]. The minimum and maximum values for the overall energetic efficiency are summarised in Figure 3 for the selected biofuel options and associated raw materials.

As represented in available international publications, for conventional biofuels like biodiesel and bioethanol, specific raw materials (e.g., distinction between different oil crops, sugar or starch biomasses) could be evaluated (Table 1). For other options like hydrotreated vegetable oils/hydroprocessed esters and fatty acids (HVO/HEFA) as well as especially bioethanol and synthetic fuels based on lignocellulosic biomass, this distinction is difficult. Therefore, raw material classes were summarised. For HVO/HEFA, this class is oil crops with palm on the lower and rape on the upper level of the given bandwidth. For bioethanol and synthetic fuels, it is lignocelluloses with wood and straw as well as for biomethane/biogas different silages (e.g., from maize or grass).

Keeping in mind the IEA road map, conventional biofuels with a high technology readiness level (TRL) (Table 1), such as biodiesel based on rape or soya and HVO/HEFA, show the highest overall conversion efficiencies. Certain bioethanol options (e.g. based on cereals and sugar beet) also show high energetic efficiencies. Depending on the silage type, the biofuel production efficiencies for biomethane/biogas show a wide range. Similarly for biofuels based on lignocellulose biomass with a comparably lower TRL (Table 1), biomethane/synthetic natural gas (SNG) can be produced very efficiently. However, it has to be noted that the specific plant design, as well as the regional conditions of a particular plant (e.g. raw material, by-products, regional infrastructure), plays a decisive role.

In general, the conversion ratio of raw material to the main biofuel product is the most important driver of the plants' energetic efficiency. By-products (Table 1) were also considered important to the overall biofuel plants' efficiency; therefore, their energetic value was also considered in the calculation, independent of their further use (e.g., as fodder or intermediate for the chemical industry). This is especially true for biodiesel (e.g., extraction meal and glycerine), bioethanol (e.g., DDGS, lignin fractions) and biomass-to-liquids/Fischer-Tropsch (BTL/FT) (e.g., naphtha). If considering the conversion ratio from raw material to biofuel, the energetic gross efficiency usually is quite lower compared to the overall energetic conversion efficiency.

When viewing Figure 3, it has to be considered that the values shown for comparison are across a mix of technology designs and TRL levels, from new production plants (also for conventional biofuels with high TRL), to pilot stage plant concepts and theoretical expectation plant concepts (e.g., for BTL and biomethane via SNG with lower TRL) and all assumed at nominal load (i.e. idealised operations). In reality, the values of such plants in operation might be considerably lower.

\section{Economic comparison-production costs}

Without economic viability, market implementation of biofuels is unlikely to be successful. To estimate more detailed biofuel production costs, different parameters

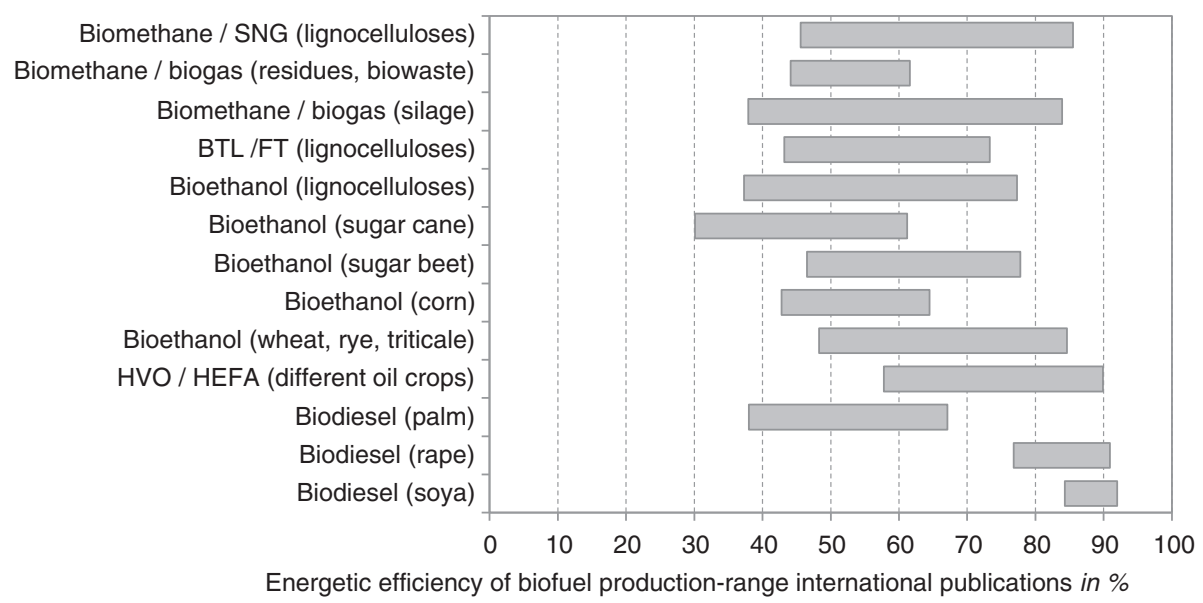

Figure 3 Comparison of energetic efficiency for biofuel production plants (calculation based on data from [17-24]; cf. [5]). 
due to regional conditions and appropriate time horizons have to be considered. The following parameters are usually included: (i) capital expenditures (CAPEX; including total capital investments, equity and leverage, interest rates, life time of plant devices, maintenances), (ii) variable operational expenditures (OPEX; raw material, auxiliaries, residues, annual full load), (iii) fixed OPEX (personnel, servicing, operation, insurances) and (iv) revenues (e.g., for by-products).

Sensitivity analyses are carried out in order to have a better understanding of the relative change of total biofuel production costs and thus analyse uncertainties. Usually, they show that besides the annual full load hours of the plant, variable OPEX (especially raw material) and CAPEX are of major importance (e.g., [11,25-27]).

Which variable OPEX factor plays the major role of the overall biofuel production costs depends on the overall plant design. It is well-known that conventional biofuels like biodiesel and bioethanol primarily depend on raw material costs. Often, market prices for raw material and by-products correlate with each other as known from conventional biofuels (e.g., oil seeds and extraction meal, starch raw materials and DDGS, Table 1). For an option like bioethanol based on lignocelluloses, by-products (e.g., lignin fractions and innovative products out of it) also occur that often are innovative and for which market prices are highly uncertain today. Moreover, the conversion efficiency plays an important role for the costs as well; biofuels with a high overall efficiency (Figure 3) show the tendency to deal with a wider raw material cost range than others. For lignocellulosic bioethanol also costs for auxiliaries (especially for enzymes e.g., for hydrolysis) are a sensitive factor. Concepts that require a lot of external process energy also show a high OPEX share.

Total capital investments (TCI) are of crucial importance with regard to financial risks and the CAPEX. Taking into account the state of technological development (Table 1), there are different approaches used for calculating the TCI (e.g. so-called rough, study, or permission estimations), all with different accuracies and financial uncertainties $[28,29]$. For commercial concepts, approval estimations can be used with an accuracy range of $5 \%-15 \%(+/-)$. Study estimations with an accuracy of $20 \%-30 \%(+/-)$ are often applied for concepts at pilot or demonstration stage. Usually, there is a range of TCI values for the different biofuel options (e.g. $[5,11,30]$ ), which is primarily due to the influence of different plant designs and regional conditions. However, there is a tendency for biomethane and biofuels based on lignocelluloses towards increasing TCI values, due to the often more complex technologies and plant designs and to the higher associated capital risks, when compared to conventional biofuels $[5,26]$. For the different plant units, specific
TCI values decrease with increasing plant sizes (effect of economy of scale). But there is a continuous cost increase in the engineering and construction industries that cannot easily be reflected. The price development of chemical facilities and machinery (including biofuel production plants) is commonly indexed by means of the so-called Chemical Engineering Plant Cost Index (CEPCI) or the Kölbel-Schulze methodology [31]. According to KölbelSchulze price index, the TCI has increased by about $6.5 \%$ in the period 2010-2013 [32]. Biofuel options with high TCI (especially bioethanol, biomethane and BTL) often are associated with high CAPEX and are highly sensitive to annual full load hours of operation.

Certain plant designs and overall concepts, as well as different methodical approaches with different regional frame conditions, time horizons, scenarios and cost parameters, make a comprehensive comparison of publications difficult. The literature reviewed for the economic survey includes publications from the past seven years. Therefore, in order to normalise the production costs given in different currencies and for different years, the values were first converted to EUR $\mathrm{GJ}^{-1}$ using the annual average exchange rates [33]. After which, they were normalised to the year 2013, by means of the cumulated inflation rates (as annual average of the EU, [34]). The range of available production costs for the different biofuel options are presented in Figure 4. Moreover, values published by DBFZ are indicated (e.g., white dot), which were calculated for exemplarily overall biofuel concepts for which detailed data (e.g., for mass and energy balances and cost parameters) have been available with a common methodology (dynamic annuity approach) and basic assumptions.

According to this, the lowest biofuel production costs were associated with palm-based biodiesel and sugar cane-based bioethanol. In comparison to conventional biofuels, lignocellulosic-based biofuels are usually more cost intensive. Especially for BTL fuels based on lignocellulosic biomass (TRL of 6 , Table 1 ), the range is especially wide, which is primarily caused by many different concept approaches and thus the assumptions behind. For lignocellulosic bioethanol for instance (TRL of 7, Table 1), there is the potential to develop overall concepts in such a way that they could be produced at lower costs compared to the conventional biofuels [38].

Considering the development of biofuel production costs in the future, there are many other influencing factors. For instance, the development of raw material prices (usually commodities like cereals, oil crops or lignocellulosic biomass) may be influenced by e.g. impacts from climate change or productivity gains in agriculture and crop losses. Also, the development of crude oil prices is relevant and coupled to multifunctional dependencies of input factors (e.g., the influence on raw materials, plant 


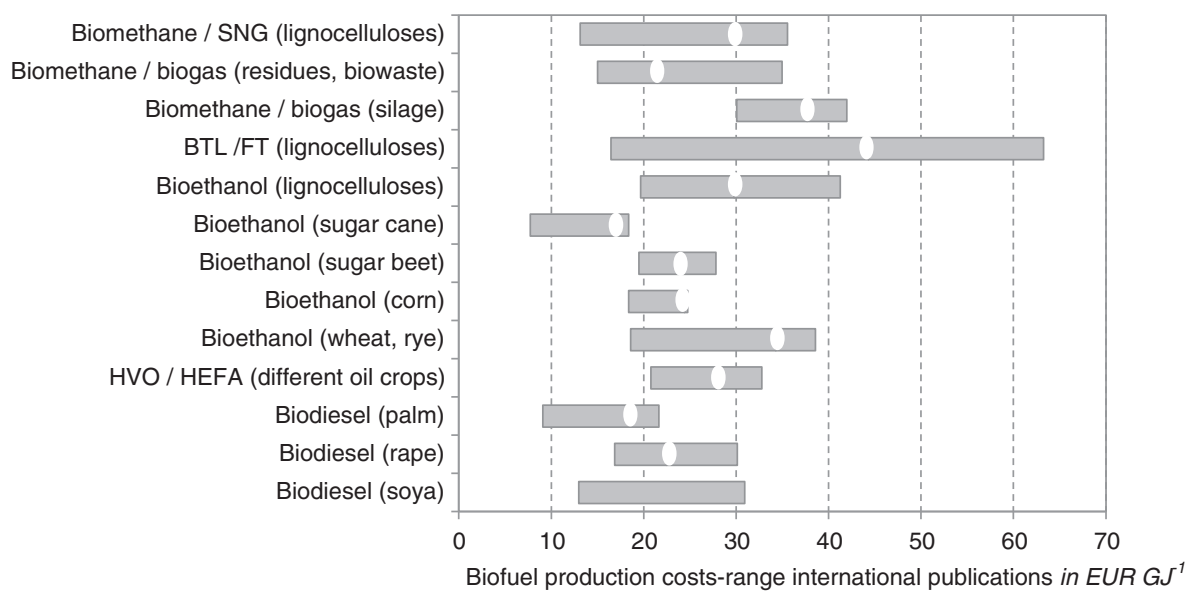

Figure 4 Comparison of biofuel production costs (based on $[\mathbf{2 , 3}, \mathbf{1 8 , 2 0 , 2 1 , 2 5 , 2 7 , 3 1 , 3 5 - 4 1 ] ) . ~ W h i t e ~ d o t s ~ i n d i c a t e ~ c o s t ~ v a l u e s ~ f o r ~ e x e m p l a r i l y ~}$ concepts by DBFZ in $[2,20,21,35,38,42])$.

devices and equipment, transport as well as their uncertain dependencies amongst each other). Moreover, it has to be noted that different market interdependencies which have featured correlations in the past may not show the same behaviour in the future due to a lack of causality (spurious correlation). Cost reductions for biofuels (especially regarding options with a lower TRL, Table 1), effects of scaling and learning mainly depend on the development of cumulated installed capacities and utilised plant sizes. However, technology, regional factors and point in time will be influential for that. This is also true for political conditions and technological breakthroughs [37].

After pointing out the relevant variables involved in the calculation and interpretation of economic trends and data, in the end the overall economic efficiency of a plant currently and in the future depends very much on the plants' unique situation.

\section{Environmental comparison-GHG performance}

Biofuels are promoted as a better alternative to fossil transport fuels, in order to reduce the GHG emissions of the transport sector [43-46]. For this reason, GHG mitigation potential, relative to the fossil fuel it displaces, is the most considered environmental performance indicator of a biofuel. Life cycle analysis (LCA) is a methodology typically applied for estimating the potential GHG emissions and mitigation potential of a biofuel chain [47-51], across the whole spectrum of the biofuel supply chain, from 'well-to-wheel' (feedstock production to utilisation) or from 'well-to-gate' (raw material production to biofuel produced). Biomass production and conversion are in general associated with the highest emissions, resulting in the reduced GHG mitigation potential of a biofuel [52,53]. Some key drivers for calculating the
GHG emissions associated with these steps are outlined in Table 2.

Biomass production is decentralised by nature $[66,67]$ and is quite often intrinsically linked to intense regionalised agricultural production [68-70]; these biomass cropping systems can vary extensively regarding management (e.g., fertiliser demand and rotations), growing season, yields and system losses (e.g., ammonia volatilisation and run off); all these factors affect the associated GHG emissions for biomass production [71]. In particular, the application of nitrogen fertiliser for increased yields and land use change (LUC) to produce more biomass can contribute significantly to the GHG emissions of a biofuel chain (Table 2). For most LCA studies, nitrogen fertiliser application is found to contribute significantly to both direct GHG emissions (e.g., field emissions) and indirect (energy-intensive fertiliser production, e.g. Haber-Bosch process) [72-75]. Modifying land utilisation or shifting in land use patterns can alter soil carbon dynamics, potentially resulting in either GHG saving or losses [76-81]. This can also contribute to direct or indirect emissions of a biofuel chain. However, uncertainties remain for determining the appropriate means of calculating and accounting for the associated emissions from both fertiliser application and LUC (Table 2).

The GHG emissions from biomass conversion to biofuels are driven by the use of auxiliary materials (e.g., process chemicals), process heat (from both the production of the energy carrier used for heat supply (e.g., natural gas) and from the heat production itself (e.g., burning of the natural gas)), as well as power (e.g., electricity from the public grid) required for processing biomass. Upstream emissions contribute significantly to the emissions associated with the use of auxiliaries, heat and electrical power. Therefore, due to the often complex 
Table 2 Overview of drivers of GHG in biomass production and biofuel conversion systems and associated uncertainties in accounting for these drivers within the LCA method

\begin{tabular}{|c|c|c|c|}
\hline Pathway step & Drivers of GHG emissions & Relevant aspects & Uncertainties related to drivers \\
\hline \multicolumn{4}{|l|}{ Biomass production } \\
\hline \multirow[t]{5}{*}{ Oil, sugar, starch, lignocellulosic ${ }^{a}$} & $\mathrm{dLUC/iLUC} C^{b}$ & Change in carbon stocks $[54,55]$ & Carbon inventory \\
\hline & & & Lack of primary data \\
\hline & $\begin{array}{l}\text { Biomass management practices } \\
\text { for increased yields }[52,56]\end{array}$ & $\begin{array}{l}\text { Nitrogen }(\mathrm{N}) \text { fertiliser use and } \\
\mathrm{N} \text { loses }^{\mathrm{e}}[57-62]\end{array}$ & $\begin{array}{l}\text { Amount of } \mathrm{N}_{2} \mathrm{O} \text { releases }{ }^{\mathrm{h}} \text { associated } \\
\text { with parameters mentioned [58] }\end{array}$ \\
\hline & Cultivation and transport [18] & Fuel consumption $^{f}$ & $\begin{array}{l}\text { Parameters influencing fuel } \\
\text { consumption }\end{array}$ \\
\hline & & Soil compaction [63] & $\begin{array}{l}\text { Lack of primary data/site specificity } \\
\text { for soil compaction and GHG } \\
\text { emissions }\end{array}$ \\
\hline
\end{tabular}

Biofuel conversion

Biodiesel, HVO/HEFA, bioethanol, Energy consumption BTL/FT Biomethane

Auxiliary materials ${ }^{c}$

Overall conversion efficiency ${ }^{d}$
Upstream emissions from fossil and renewable energy chains ${ }^{9}$

Upstream emissions due to the production of required chemicals/catalysts ${ }^{9}$
Uncertainties related to the emission factors for energy production ${ }^{i}$

Use of generic values taken from available databases e.g., Ecoinvent [64], NREL

The overall efficiency of the biomass used has an impact on the upstream emissions from biomass production per MJ of biofuel
Uncertainties related to data availability for the assessment of advanced biofuel technologies [56]

\footnotetext{
aLignocellulosic raw materials, cf. Table 1.

${ }^{\mathrm{b}}$ Land use change occurs when areas not used for agricultural purposes (e.g., forest areas and grasslands) are converted to produce biomass, indirect LUC (iLUC) can occur when existing agricultural areas and non-agricultural areas are converted to other crops/land uses to meet demands for increasing demands for bioenergy and agricultural products [65].

${ }^{c}$ Auxiliary materials (e.g., process chemicals and catalysts).

${ }^{\mathrm{d} C f}$. Section 3.

${ }^{\mathrm{e}} \mathrm{N}$ fertiliser use refers to type of fertiliser used e.g., calcium ammonium nitrate or urea.

f Variability in fuel consumption due to soil conditions at harvesting, machinery used, field structure, distance to intermediate storage or bioenergy plant, etc. ${ }^{9}$ The term upstream emissions refer to the emissions associated with the production and provision of the energy carriers or materials used (e.g., emissions from the production of electricity provided via the public grid and used in the biomass conversion process).

${ }^{\mathrm{h}}$ The amount of $\mathrm{N}_{2} \mathrm{O}$ emitted from biomass production depends on a number of parameters such as, type of fertiliser, application technique and time, crop rotation systems, climate, soil types, etc..

'Uncertainties associated with the upstream emissions from the production of the energy used for conversion processes (e.g., electricity from public grid) refer to the many different processing scales and technologies involved.

jUncertainties in relation to data/data sources available on the various drivers and relevant aspects. NREL, National Renewable Energy Laboratory.
}

global production networks involved in producing such auxiliaries, energy carriers and grid energy, the calculated upstream GHG emissions are associated with a number of uncertainties (Table 2) [82].

In spite of all uncertainties and debates, LCA calculations provide a valuable indication of the global warming potential [83] and GHG mitigation potential of a biofuel. In relation to these calculations and as pointed out in the previous sections, the plant concepts for each biofuel pathway are unique to each individual plant and regional conditions. Accordingly, LCA studies for a particular biofuel are also unique, depending on the specific research question or context of the study (goal and scope), the assumptions made (e.g., system boundaries, cut-off criteria, allocation of by-products) as well as the spatial and temporal characteristics of the processes assessed. While this is very important for making the assessment of the particular case study, it makes the results from different LCA studies difficult to compare [48]. Therefore, care must always be taken when comparing across different conversion pathways, particularly when drawing comparisons across current biofuel options with a high TRL (e.g., rapeseed biodiesel) with advanced or future biofuels with a lower TRL (e.g., BTL), for which currently no real plant operational data is available. The ranges of GHG emissions found in the literature for the selected biofuel options in this study are outlined in Figure 5. Each LCA study used to show this range are case specific, as they all refer to specific facilities designs and configurations.

\section{GHG mitigation costs}

Various regions and countries are currently promoting the use of biofuels. Often, mandatory quotas and blending targets are used as supportive political instruments to achieve defined biofuels targets. While most policy instruments are aiming at energetic targets for biofuels, environmental characteristics are becoming more relevant in some regions (e.g. in Europe). One country in particular, Germany, will introduce a GHG-related biofuel quota in the year 2015 [9]. Therefore, it is plausible due to this policy alteration; GHG mitigation costs may become one 


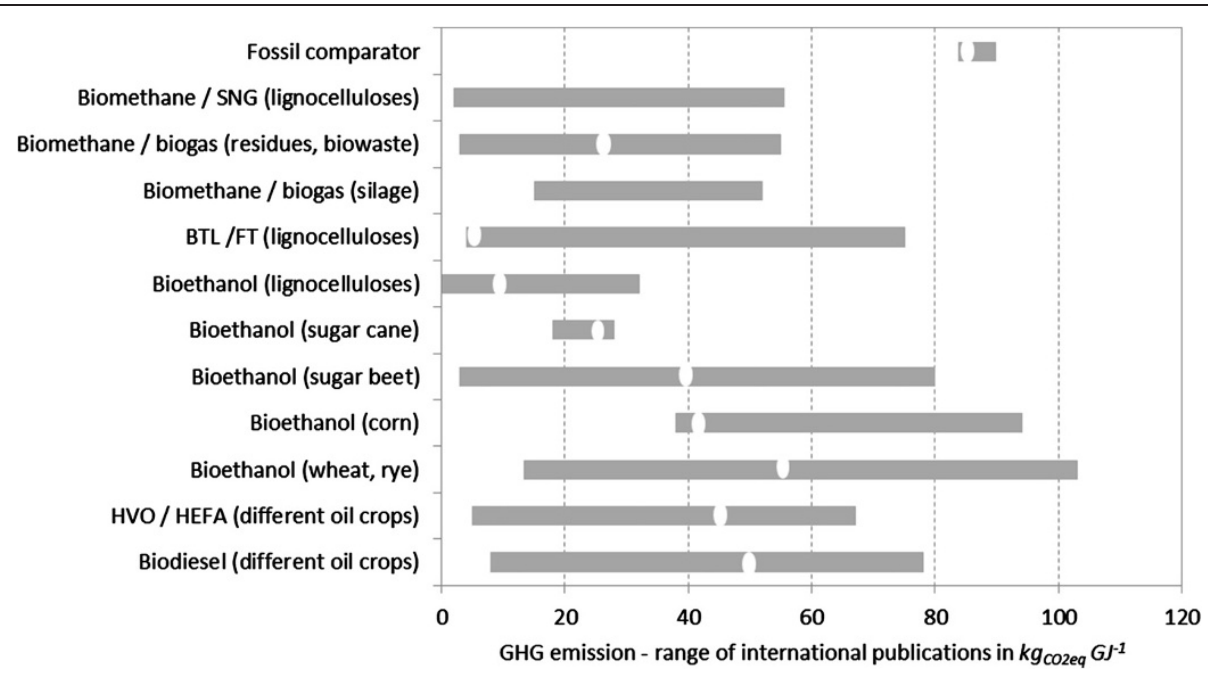

Figure 5 Comparison of GHG emissions (based on $[\mathbf{9 , 1 1 , 1 5 , 1 8 , 2 3 , 2 4 , 3 7 , 5 2 , 8 4 - 8 6 ] ) . ~ W h i t e ~ d o t s ~ i n d i c a t e ~ t h e ~ d e f a u l t ~ v a l u e s ~ f o r ~ t h e ~ b i o f u e l ~}$ pathways included in Annex V of the EU Directive 2009/28/EC [7] — rape seed biodiesel for biodiesel (different oil crops), rapeseed HVO for HVO/HEFA (different oil crops).

of the most important benchmarks for biofuel producers, in order to establish their competitive edge over other biofuel options on the German market, or indeed being introduced to the German market.

The term GHG mitigation costs represents the additional costs requirements for the production of a biofuel, in order to have a unit reduction in GHG emissions (in well-to-wheel terms) in comparison to its fossil equivalent (Figure 5). This parameter, although associated with various uncertainties, as outlined in the previous sections, could be very useful when estimating the cost of avoiding the global warming potential of fuels.

Combining the three aspects outlined in this paper, technical efficiency, cost and GHG mitigation potential, a very simple approach was taken to estimate the potential GHG mitigation costs presented in Figure 6. These calculations are based on the standard GHG emission value provided in Annex $\mathrm{V}$ of the EU (RED) Directive 2009/28/EC for each specific biofuel option [7,9]. The default value for a specific biofuel option can be used by biofuel producers to calculate the GHG mitigation potential of their fuel relative to a fossil equivalent; therefore, it seemed fitting to use these default values in the calculations presented in this paper. The default values are also shown within the GHG ranges outlined in Figure 5 to indicate where these default values fell in the range of the literature selected for this study. The range of costs associated with producing a particular biofuel was taken from the studies outlined in Section Economic comparison-production costs and also include DBFZ own values (Figure 4).

The fossil comparator used for the calculation was assumed to be a mixture of gasoline/diesel, in a ratio of
$35 \%-65 \%$, (based on the fuel consumption for the transport sector in Germany according to [87], with a GHG value of $83.8 \mathrm{~kg} \mathrm{CO}_{2 \text { eq. }} \mathrm{GJ}^{-1}$ according to [7]. The average product price (excluding any taxes) of $16.7 \mathrm{EUR} \mathrm{GJ}^{-1}$ for 2013 was calculated, considering the mentioned fossil fuel mixture based on $[88,89]$.

With regards to Figure 6, only the ranges should be considered and not the absolute values, as these are only to provide an indication of potential GHG mitigation costs, in reality as outlined in Section Economic comparison-production costs; calculations based on actual detailed values from biofuel producers could differ from those presented here. A negative GHG mitigation costs could also theoretically result from those biofuel options which have lower production costs and GHG emissions than that of the fossil equivalent.

\section{It is likely with a GHG-based biofuel quota, biofuel options with the lowest GHG mitigation costs will be sold to the market first}

According to the DBFZ-derived values, the biofuels which show a good mitigation cost potential are soya-based biodiesel, sugar cane-based bioethanol, biomethane, palmbased biodiesel and corn bioethanol. Lignocellulosic bioethanol might have comparable GHG mitigation costs like corn bioethanol and rape-based biodiesel. However, this can be explained mainly by the rather low GHG default value for lignocellulosic bioethanol (compared to the literature values indicated in Figure 5). Options like HVO/ HEFA, BTL and cereal-based bioethanol show comparably higher GHG mitigation costs. This is caused by comparably higher TCI, and in the case of bioethanol, raw material prices are also a factor. 


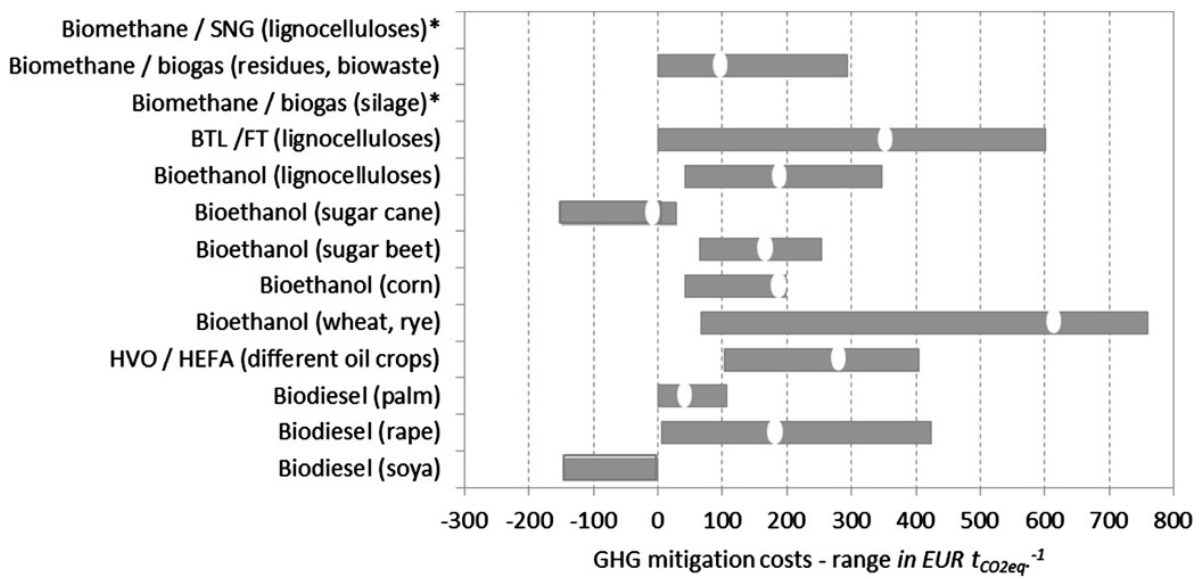

Figure 6 GHG mitigation costs. White dots indicate the reduction costs calculated with the RED default values and the cost values published by DBFZ (indicated as white dots in Figure 4; please note that there is no DBFZ value for soya biodiesel). *No GHG standard values according to RED [7].

\section{Discussion and conclusions}

The aim of this article was to provide an overview of the most relevant criteria for comparing biofuel options outlined in the IEA biofuels roadmap. Each of these biofuel options has its own particular characteristics from typical raw materials, to conversion processes, by-products, as well as their state of technical development and various R\&D challenges.

The development of biofuel technologies and their market implementation is highly dependent on specific policy conditions. In fact, despite their specific fuel properties (e.g. with regard to drop in use in the different transport sectors and standards), important indicators to assess the potential success of a biofuel in the market relate to its overall production costs and GHG mitigation performance, which are amongst others, driven by energetic efficiency and biomass-to-biofuel conversion efficiency.

The combination of these aspects to estimate the potential GHG mitigation costs of a biofuel may also be an important benchmark for biofuel producers in Germany from 2015 onwards. The introduction of a GHG-based quota could result in GHG mitigation costs being an important driver for market sale. Consequently, biofuel options with the lowest mitigation costs will enter the market first.

From the results presented in this paper, no clear conclusion can be made to indicate a 'champion' biofuel option, with regard to high overall energetic efficiencies, low cost and low GHG emissions. It is difficult to effectively state one biofuel option is better than another, as each biofuel plant has its own specific plant design and unique set of regional conditions (e.g., raw material, auxiliaries and infrastructures), by-products; therefore, an appropriate comparison needs to somehow account for all these variances. Furthermore, the decarbonisation strategy of the EU and national approaches such as the German GHG quota are introducing incentives to optimise existing and future biofuel options. A direct comparison of biofuels based on current literature values can therefore only be seen as a starting point to consider these new incentives on the investigated indicators (e.g., GHG emissions).

It is very difficult to benchmark a biofuel within a market sector that is constatnly undergoing changes. The biofuel market is very sensitive to global and regional policy e.g. targets for renewable fuels until 2020 and beyond, as well as market interventions such as subsidise and support schemes. One major contributor to fluctuating market conditions is the price developments of mineral oil and this is a key consideration in the bench mark of a biofuel. There is also the challenge of societal acceptance, which leads invariably to further market variability. However, there is ever increasing attention being given to biorefinery concepts, which are promoted to maximise biomassto-products ratio, as biorefineries are multiproduct facilities (e.g. biofuels, bulk chemicals, feed and food, energy). Through the diversification of biomass-based products, such plants may not be so susceptible to market shifts.

Referring to the sector of application (here energy or transport sector), GHG mitigation costs might become one of the most important factors describing the competitiveness of a biofuel in future markets. Since biofuel production costs are mainly driven by raw material prices with rather low reduction potentials, the optimisation of biofuel production with regards to GHG emissions will be a decisive aspect for the future of current biofuel options such as biodiesel (e.g. from vegetable oils).

While the GHG cost mitigation is a good start to combining the environmental and economic benefits of the different biofuel options, it has to be noted that focusing only on GHG mitigation potential may lead to a shifting of the environmental burdens for producing one GJ of 
biofuel to cause other environmental and ecological impacts [90], such as eutrophication and biodiversity loss [91-93], thus effectively counteracting the whole principle of conducting LCAs in the first place. As is the case with all the indicators outlined in this paper, the greatest challenge in the future will be to include and integrate the complexities associated with biofuel production, to include more complex aspects such as regional and spatial impacts [90,94-100], biodiversity [91-93] and socioeconomic impacts [93] and to avoid the shifting of environmental burdens in a cost-effective manner, including more regional and spatial aspects. However, the application of a GHG mitigation cost potential could be the start along the road which leads to the development of effective assessments.

\footnotetext{
Abbreviations

BTL: biomass-to-liquids; CAPEX: capital expenditures; DDGS: distiller's grains with solubles; DME: dimethylester; dLUC: direct land use change; eq: equivalent; EU: European Union; EUR: euro; FAME: fatty acid methyl ester; FT: Fischer-Tropsch; GHG: greenhouse gas; HEFA: hydroprocessed esters and fatty acids; HVO: hydrotreated vegetable oils; iLUC: indirect land use change; LCA: life cycle analysis; LUC: land use change; N: nitrogen; NREL: National Renewable Energy Laboratory; mn: million; OPEX: operation expenditures; P\&H (electrical): power and heat; R\&D: research and development; SNG: synthetic natural gas; TCl: total capital investments; TRL: technology readiness level; UCO: used cooking oil; US: United States of America.
}

\section{Competing interests}

The authors declare that they have no competing interests.

\section{Authors' contributions}

FML carried out the technical part as well as the technical and economic analysis and conceived of the papers structure. SM and SOK conducted the environmental analysis. SM and FML did the calculations on the GHG mitigation costs. All authors drafted, read and approved the final manuscript.

\section{Acknowledgements}

The authors would like to thank the Dagmar Fiedler and the guest editors Professor Detlef Stolten and Professor Viktor Scherer for inviting us, writing an article based on the contribution we already made for the Third International Conference on Energy Process Engineering' in 2013 (cf. [4]). Moreover, we would also like to thank the reviewers for their valuable feedback and for helping to improve the final version of our article.

\section{Author details}

'Department Biorefineries, Deutsches Biomasseforschungszentrum gemeinnützige GmbH, Torgauer Straße 116, 04347 Leipzig, Germany. ${ }^{2}$ Department Bioenergy Systems, Deutsches Biomasseforschungszentrum gemeinnützige GmbH, Torgauer Straße 116, 04347 Leipzig, Germany. ${ }^{3}$ Department Bioenergy, UFZ Helmholtz Centre for Environmental Research, Torgauer Straße 116, 04347 Leipzig, Germany.

Received: 25 March 2014 Accepted: 4 September 2014

Published online: 03 October 2014

\section{References}

1. IEA (2011) World energy outlook 2011. International Energy Agency, Paris

2. Naumann K, Oehmichen K, Zeymer M (2014) Monitoring Biokraftstoffsektor. DBFZ Report 11, 2. Auflage, 2014 ISSN 2190-7943

3. IEA (2011) Technology roadmaps-biofuels for transport. International Energy Agency, Paris

4. Thrän D, Bunzel K, Seyfert U, Zeller V, Buchhorn M, Müller K, Matzdorf B, Gaasch N, Klöckner K, Möller I, Starick A, Brandes J, Günther K, Thum M, Zeddies J, Schönleber N, Gamer W, Schweinle J, Weimar H (2011) Global and regional spatial distribution of biomass potentials—status quo and options for specification. Deutsches Biomasseforschungszentrum, Leipzig
5. Müller-Langer F, Gröngröft A, Majer S, O'Keeffe S (2013) Klemm M (2013) Options for biofuel production - status and perspectives. In: Stolten D, Scherer $V$ (eds) Transition to renewable energy systems. Wiley-Verlag, Weinheim, pp 523-553, doi:10.1002/9783527673872.ch26)

6. Zarrilli S, Burnett J (2008) Making certification work for sustainable development: the case of biofuels. United Nations, New York and Geneva

7. European Union (2009) DIRECTIVE 2009/28/EC OF THE EUROPEAN PARLIAMENT AND OF THE COUNCIL of 23 April 2009 on the promotion of the use of energy from renewable sources and amending and subsequently repealing Directives 2001/77/EC and 2003/30/EC. Official Journal of the European Union

8. European U (2009) DIRECTIVE 2009/30/EC OF THE EUROPEAN PARLIAMENT AND OF THE COUNCIL of 23 April 2009 amending Directive 98/70/EC as regards the specification of petrol, diesel and gas-oil and introducing a mechanism to monitor and reduce greenhouse gas emissions and amending Council Directive 1999/32/EC as regards the specification of fuel used by inland waterway vessels and repealing Directive 93/12/EEC. Official Journal of the European Union

9. Federal Republic of Germany (2009) Gesetz zur Änderung der Förderung von Biokraftstoffen vom 15. Juli 2009 (BGBI. I S 1804)

10. Kaltschmitt M, Hartmann H, Hofbauer H (2009) Energie aus Biomasse: Grundlagen, Techniken und Verfahren. Auflage: 2. Springer, Berlin

11. Müller-Langer F, Majer S, Perimenis A (2012) Biofuels—a technical, economic and environmental comparison. In: Meyers RA (ed) Encyclopedia of sustainability science and technology. Springer, New York, ISBN/EAN: 978-0-387-89469-0

12. Bacovsky D, Dallos M, Wörgetter M (2010) Task IEAB (2010) Status of 2nd generation biofuels demonstration facilities in june

13. Lorne D, Chabrelie M-F (2010) New biofuel production technologies: overview of these expanding sectors and the challenges facing them. IFP Energies nouvelles, Cedex

14. Commission E (2011) High-level expert group on key enabling technologies. European Commission, Brussels

15. Skone T (2012) Scenario uncertainties in estimating direct land-use change emissions in biomass-to-energy life cycle assessment. Biomass Bioenergy 47:240-249

16. Marten GG (1982) Land use issues in biomass energy planning. Resources Policy 8(1):65-74

17. Deutsches Biomasseforschungszentrum gemeinnützige $\mathrm{GmbH}$ (2013) Database of bioenergy concepts., 2008-2013

18. Edwards R, Larivé J-F, Mahieu V, Rouveirolles P (2007) Well-to-wheels analysis of future automotive fuels and powertrains in the European context-well-to-tank report and appendices. EUCAR and CONCAWE, Luxembourg

19. Jungbluth N, Chudacoff M, Dauriat A, Dinkel F, Doka G, Faist Emmenegger M, Gnansounou E, Kljun N, Spielmann M, Stettler C, Sutter J (2007) Life cycle inventories of bioenergy. Swiss Centre for Life Cycle. Inventories, Dübendorf

20. Müller-Langer F, Perimenis A, Brauer S, Thrän D, Kaltschmitt M (2008) Expertise zur technischen und ökonomischen Bewertung von Bioenergie-Konversionspfaden. WBGU, Berlin

21. Müller-Langer F, Junold M, Schröder G, Thrän D, Vogel A (2007) Analyse und Evaluierung von Anlagen und Techniken zur Produktion von Biokraftstoffen. Institut für Energetik und Umwelt, Leipzig

22. Nikander S (2008) Greenhouse gas and energy intensity of product chain: case transport biofuel

23. Rettenmaier N, Reinhardt G, Gärtner S, Von Falkenstein E (2008) Greenhouse gas balances for VERBIO ethanol as per the German biomass sustainability ordinance (BioNachV). ifeu—Institut für Energie- und Umweltforschung gGmbH, VERBIO, Heidelberg

24. Rettenmaier N, Reinhardt G, Münch J, Gärtner S (2007) Datenprojekt "Nachwachsende Rohstoffe. Netzwerk Lebenszyklusdaten, Arbeitskreis Nachwachsende Rohstoffe, Heidelberg

25. Vogel A, Brauer S, Müller-Langer F, Thrän D (2008) Renew-renewable fuels for advanced powertrains-deliverable d 5.3.7-conversion costs calculation. Deutsches Biomasseforschungszentrum, Leipzig

26. De Wit M, Junginger M, Lensink S, Londo M, Faaij A (2010) Competition between biofuels: modeling technological learning and cost reductions over time. Biomass Bioenergy 34(2):203-217

27. Doornbosch R, Steenblik R (2008) Biofuels: is the cure worse than the disease? Revista Virtual REDESMA 2:63-100 
28. Bernecker $\mathrm{G}$ (2001) Planung und Bau verfahrenstechnischer Anlagen, 4th edn. Springer, Berlin

29. Schembra M, Schulze J (1993) Schätzung der Investitionskosten bei der Prozessentwicklung., Chemie Ingenieur Technik 65, Nr. 1, S, pp 41-47

30. Zinoviev S, Müller-Langer F, Das P, Bertero N, Fornasiero P, Kaltschmitt M, Centi G, Miertus S (2010) Next-generation biofuels: survey of emerging technologies and sustainability issues. ChemSusChem 3:1106-1133

31. Ong HC, Mahlia TMI, Masjuki HH, Honnery D (2012) Life cycle cost and sensitivity analysis of palm biodiesel production. Fuel 98:131-139

32. CHEMIE TECHNIK exklusiv (2014) Preisindex für Chemieanlagen. http://www.chemietechnik.de/bildergalerien/anzeigen/6134/2/text/120444/ CT-Exklusiv-Baupreisindex-fuer-Chemieanlagen. (access 03/2014)

33. Eurostat (2014) Exchange rates exchange rates (annual average), cf. http://epp.eurostat.ec.europa.eu/tgm/table.do?tab=table\&init=1\&plugin= 1\&language $=$ en\&pcode $=$ tec00033 (access 03/2014)

34. Eurostat (2014) Inflation rate (annual average) in EU, cf. http://epp.eurostat.ec.europa.eu/tgm/table.do?tab=table\&init=1\& plugin $=1$ \&language $=$ en\&pcode $=$ tec00118 (access 03/2014)

35. Müller-Langer F, Rönsch S, Weithäuser M, Oehmichen K, Seiffert M, Majer S, Scholwin F (2009) Erdgassubstitute aus Biomasse für die mobile Anwendung im zukünftigen Energiesystem. Endbericht zum Forschungsvorhaben FZK 22031005. Fachagentur Nachwachsende Rohstoffe e. V, Gülzow

36. Sims REH, Mabee W, Saddler JN, Taylor M (2010) An overview of second generation biofuel technologies. Bioresour Technol 101:1570-1580

37. Perimenis A, Majer S, Zech K, Holland M, Müller-Langer F (2010) Deliverable D5 (WP 4 report), lifecycle assessment of transportation fuels, TOSCA-Technology Opportunities and Strategies towards Climate Friendly Transport FP7-TPT-2008-RTD-1

38. Zech K, Brosowski A, Meisel K, Müller-Langer F (2013) Deliverable 13.7 Economic assessment of the scenario variations FP7-ENERGY-2008-TREN-1 KACELLE-KALundborg CELLulosic BioEthanol. to be published

39. Schade B, Wiesenthal T (2011) Biofuels: a model based assessment under uncertainty applying the Monte Carlo method. J Policy Model 33:92-126

40. Van Vliet OP, Faaij AP, Turkenburg WC (2009) Fischer-Tropsch diesel production in a well-to-wheel perspective: a carbon, energy flow and cost analysis. Energy Convers Manag 50:855-876

41. Sunde K, Brekke A, Solber B (2011) Environmental impacts and costs of hydrotreated vegetable oils, transesterified lipids and woody BTL-a review. Energies 2011(4):845-877

42. Müller-Langer F, Kaltschmitt M (2014) Biofuels from lignocellulosic biomass - a multi-criteria approach for comparing overall concepts. Biomass Conversion and Biorefinery. doi:10.1007/s13399-014-0125-7

43. European Commission (2011) Technology map: a European strategic energy technology plan (set-plan) technology descriptions. Joint Research Centre Institute for Energy and. Transport, Luxemburg

44. Gnansounou E, Dauriat A (2011) Chapter 2-Life-cycle assessment of biofuels. In: Pandey A (ed) Alternative Feedstocks and Conversion Processes Academic Press, 2011., ISBN 0123850991

45. OECD IEA (2013) Sustainable production of second generation biofuels. Potential and perspectives in major economies and developing countries, Paris

46. Bare JC (2010) Life cycle impact assessment research developments and needs., pp 341-351

47. Cherubini F (2010) GHG balances of bioenergy systems-overview of key steps in the production chain and methodological concerns., pp 1565-1573

48. Reap J, Roman F, Duncan S, Bras B (2008) A survey of unresolved problems in life cycle assessment., pp 374-388

49. Rebitzer G, Ekvall T, Frischknecht R, Hunkeler D, Norris G, Rydberg T, Schmidt W-P, Suh S, Weidema BP, Pennington DW (2004) Life cycle assessment: part 1: framework, goal and scope definition, inventory analysis, and applications., pp 701-720

50. Guinée J, Heijungs R, Voet E (2009) A greenhouse gas indicator for bioenergy: some theoretical issues with practical implications., pp 328-339

51. Zah R, Böni H, Gauch M, Hischier R, Lehmann M, Wäger P (2007) Ökobilanz von Energieprodukten: Ökologische Bewertung von Biotreibstoffen. EMPA, im Auftrag des Bundesamtes für Energie, des Bundesamtes für Umwelt und des Bundesamtes für Landwirtschaft, Bern

52. Hennig C, Gawor M (2012) Bioenergy production and use: comparative analysis of the economic and environmental effects. Energy Convers Manag 63:130-137
53. Dale VH, Lowrance R, Mulholland P, Robertson GP (2010) Bioenergy sustainability at the regional scale. Ecol Soc 15(4):23

54. Searchinger T, Heimlich R, Houghton RA, Dong F, Elobeid A, Fabiosa J, Tokgoz S, Hayes D, Yu T-H (2008) Use of U.S. croplands for biofuels increases greenhouse gases through emissions from land-use change., pp 1238-1240

55. Crutzen PJ, Mosier AR, Smith KA, Winiwarter W (2007) $\mathrm{N}_{2} \mathrm{O}$ release from agro-biofuel production negates global warming reduction by replacing fossil fuels., pp 11191-11205

56. Laborde D (2011) Assessing the land use change consequences of European biofuel policies. ATLAS Consortium, London

57. Paustian K et al (2006) 2006 IPCC Guidelines for National Greenhouse Gas Inventories. IPCC National Greenhouse Inventories Programme. Institute for Global Environmental Strategies (IGES), Hayama, Japan on behalf of the Intergovernmental Panel on Climate Change (IPCC)

58. Lisboa CC, Butterbach-Bahl K, Mauder M, Kiese R (2011) Bioethanol production from sugarcane and emissions of greenhouse gases-known and unknowns., pp 277-292

59. Liu XJ, Mosier AR, Halvorson AD, Reule CA, Zhang FS (2007) Dinitrogen and $\mathrm{N}_{2} \mathrm{O}$ emissions in arable soils: effect of tillage, $\mathrm{N}$ source and soil moisture., pp 2362-2370

60. Smeets EMW, Bouwman LF, Stehfest E, Van Vuuren DP, Posthuma A (2009) Contribution of $\mathrm{N}_{2} \mathrm{O}$ to the greenhouse gas balance of first-generation biofuels., pp 1-23

61. Smith P, Martino D, Cai Z, Gwary D, Janzen H, Kumar P, McCarl B, Ogle S, O'Mara F, Rice C, Scholes B, Sirotenko O (2007) Agriculture. In: Metz B, Davidson OR, Bosch PR, Dave R, Meyer LA (eds) Climate change 2007: mitigation. contribution of working group III to the fourth assessment report of the intergovernmental panel on climate change. Cambridge University Press, Cambridge and New York

62. Mosquera J, Hol JMG, Rappoldt CJD (2007) Precise soil management as a tool to reduce $\mathrm{CH}_{4}$ and $\mathrm{N}_{2} \mathrm{O}$ emissions from agricultural soils., Report 28 . ISSN, pp 1570-8616

63. Frischknecht $R$, Jungbluth $N$, Althaus H-J, Doka G, Heck T, Hellweg S, Hischier R, Nemecek T, Rebitzer G, Spielmann M, Wernet G (2007) Overview and methodology. Ecoinvent report no. 1. Swiss Centre for Life Cycle Inventories, Dübendorf

64. Alvarado-Morales M, Boldrin AB, Karakashev DL, Holdt S, Angelidaki I, Astrup T (2011) Life cycle assessment (LCA) of the biofuel production process from sunflower oil, rapeseed oil and soybean oil. Fuel Process Technol 92(2):190-199

65. Majer S, Mueller-Langer F, Zeller V, Kaltschmitt M (2009) Implications of biodiesel production and utilisation on global climate-a literature review. Eur J Lipid Sci Technol 111:747-762

66. van der Hilst F, Dornburg V, Sanders JPM, Elbersen B, Graves A, Turkenburg WC, Elbersen HW, van Dam JMC, Faaij APC (2010) Potential, spatial distribution and economic performance of regional biomass chains: the north of the Netherlands as example. Agric Syst 103(7):403-417

67. Luo L, van der Voet E, Huppes $G$, Udo de Haes H (2009) Allocation issues in LCA methodology: a case study of corn stover-based fuel ethanol. The International Journal of Life Cycle Assessment 14(6):529-539

68. McKone TE, Nazaroff WW, Berck P, Auffhammer M, Lipman T, Torn MS, Masanet E, Lobscheid A, Santero N, Mishra U, Barrett A, Bomberg M, Fingerman K, Scown C, Strogen B, Horvath A (2011) Grand challenges for life-cycle assessment of biofuels. Environmental Science \& Technology 45(5):1751-1756

69. Robertson GP, Dale VH, Doering OC, Hamburg SP, Melillo JM, Wander MM, Parton WJ, Adler PR, Barney JN, Cruse RM, Duke CS, Fearnside PM, Follett RF, Gibbs HK, Goldemberg J, Mladenoff DJ, Ojima D, Palmer MW, Sharpley A, Wallace L, Weathers KC, Wiens JA, Wilhelm WW (2008) Agriculture. Sustainable biofuels redux. Science (New York, NY) 322(5898):49-50

70. Adler PR, Del Grosso SJ, Parton WJ (2007) Life-cycle assessment of net greenhouse-gas flux for bioenergy cropping systems

71. Bouwman AF (1996) Direct emission of nitrous oxide from agricultural soils. Nutr Cycl Agroecosyst 46(1):53-70

72. Erisman J, Grinsven H, Leip A, Mosier A, Bleeker A (2010) Nitrogen and biofuels; an overview of the current state of knowledge. Nutr Cycl Agroecosyst 86(2):211-223

73. Rees RM, Augustin J, Alberti G, Ball BC, Boeckx P, Cantarel A, Castaldi S, Chirinda N, Chojnicki B, Giebels M, Gordon H, Grosz B, Horvath L, Juszczak R, Kasimir Klemedtsson Å, Klemedtsson L, Medinets S, Machon A, Mapanda F, Nyamangara J, Olesen JE, Reay DS, Sanchez L, Sanz Cobena A, Smith KA, 
Sowerby A, Sommer M, Soussana JF, Stenberg M, Topp CFE, et al (2013) Nitrous oxide emissions from European agriculture; an analysis of variability and drivers of emissions from field experiments. Biogeosciences 10(4):2671-2682

74. Smith KA, Mosier AR, Crutzen PJ, Winiwarter W (2012) The role of $\mathrm{N}_{2} \mathrm{O}$ derived from crop-based biofuels, and from agriculture in general, in earth's climate. Philosophical Transactions of the Royal Society B: Biological Sciences 367(1593):1169-1174

75. Brandao M, Mila I, Canals L, Clift R (2011) Soil organic carbon changes in the cultivation of energy crops: implications for GHG balances and soil quality for use in LCA. Biomass Bioenergy 35(6):2323-2336

76. Čuček L, Klemeš J, Kravanja Z (2012) Carbon and nitrogen trade-offs in biomass energy production. Clean Techn Environ Policy 14(3):389-397

77. Follett RF, Vogel KP, Varvel GE, Mitchell RB, Kimble J (2012) Soil carbon sequestration by switchgrass and no-till maize grown for bioenergy. Bioenergy Research 5(4):866-875

78. Georgescu M, Lobell DB, Field CB (2011) Direct climate effects of perennial bioenergy crops in the United States. Proc Natl Acad Sci 108(11):4307-4312

79. Jose S, Bardhan S (2012) Agroforestry for biomass production and carbon sequestration: an overview. Agrofor Syst 86(2):105-111

80. Tilman D, Hill J, Lehman C (2006) Carbon-negative biofuels from low-input high-diversity grassland biomass. Science 314(5805):1598-1600

81. Weidema B (1998) Multi-user test of the data quality matrix for product life cycle inventory data. The International Journal of Life Cycle Assessment 3(5):259-265

82. Dehue B, Cornelissen S, Peters D (2011) Indirect effects of biofuel production overview prepared for GBEP. Ecofys, London

83. Reinhardt G, Gärtner S, Helms H, Rettenmaier N (2006) An assessment of energy and greenhouse gases of NExBTL. IFEU, Heidelberg

84. Brauer S, Vogel A, Müller-Langer F (2008) Cost and life-cycle analysis of biofuels. UFOP, Leipzig

85. Majer S, Gawor M, Thrän D, Bunzel K, Daniel-Gromke J (2011) Optimierung der marktnahen Förderung von Biogas/ Biomethan unter Berücksichtigung der Umwelt- und Klimabilanz. Wirtschaftlichkeit und Verfügbarkeit. Biogasrat e.V, Berlin

86. McKone TE, Nazaroff WW, Berck P, Auffhammer M, Lipman T, Torn MS, Masanet E, Lobscheid A, Santero N, Mishra U, Barrett A, Bomberg M, Fingerman K, Scown C, Strogen B, Horvath A (2011) Grand challenges for life-cycle assessment of biofuels., pp 1751-1756

87. Mineralölwirtschaftsverband (2013) Zusammensetzung des Verbraucherpreises für Dieselkraftstoff, cf. http://www.mwv.de/index.php/ daten/statistikenpreise/?loc=1\&jahr=2013 (access 03/2014)

88. Mineralölwirtschaftsverband (2013) Zusammensetzung des Verbraucherpreises für Superbenzin (95 Oktan, E5), cf. http://www.mwv.de/ index.php/daten/statistikenpreise/?loc=18jahr=2013 (access 03/2014)

89. Heijungs R (2012) Spatial differentiation, GIS-based regionalization, hyperregionalization and the boundaries of LCA

90. Mutel CL, Hellweg S (2009) Regionalized life cycle assessment: computational methodology and application to inventory databases., pp 5797-5803

91. Taubert F, Frank KAH (2012) A review of grassland models in the biofuel context

92. Tilman D, Hill J, Lehman C (2006) Carbon-negative biofuels from low-input high-diversity grassland biomass., pp 1598-1600

93. Guinée JB, Heijungs R, Huppes G, Zamagni A, Masoni P, Buonamici R, Ekvall T, Rydberg T (2011) Life cycle assessment: past, present, and future. Environmental Science \& Technology 45:90-96

94. Mineralölwirtschaftsverband (2014) Mineralölstatistik, cf. http://www.mwv. de/index.php/daten/statistikeninfoportal (access 03/2014)

95. Kim S, Dale B (2009) Regional variations in greenhouse gas emissions of biobased products in the United States_corn-based ethanol and soybean oil., pp 540-546

96. Kim S, Dale BE (2005) Life cycle assessment of various cropping systems utilized for producing biofuels: bioethanol and biodiesel. Biomass Bioenergy 29:426-439

97. Potting J, Hauschild M (2005) Background for spatial differentiation in LCA impact assessment-The EDIP 2003 methodology. Danish Ministry of the Environment, Copenhagen

98. McBride AC, Dale VH, Baskaran LM, Downing ME, Eaton LM, Efroymson RA, Garten CT Jr, Kline KL, Jager HI, Mulholland PJ, Parish ES, Schweizer PE,
Storey JM (2011) Indicators to support environmental sustainability of bioenergy systems. Ecol Indic 11(5):1277-1289

99. Tessum CW, Marshall JD, Hill JD (2012) A spatially and temporally explicit life cycle inventory of air pollutants from gasoline and ethanol in the United States., pp 11408-11417

100. Engel J, Huth A, Frank K (2012) Bioenergy production and skylark (Alauda arvensis) population abundance - a modelling approach for the analysis of land-use change impacts and conservation options

\section{doi:10.1186/s13705-014-0020-x}

Cite this article as: Müller-Langer et al.: Benchmarking biofuels-a comparison of technical, economic and environmental indicators.

Energy, Sustainability and Society 2014 4:20.

\section{Submit your manuscript to a SpringerOpen ${ }^{\circ}$ journal and benefit from:}

- Convenient online submission

- Rigorous peer review

- Immediate publication on acceptance

- Open access: articles freely available online

High visibility within the field

- Retaining the copyright to your article

Submit your next manuscript at $\gg$ springeropen.com 